\title{
Psychosocial Stress and Wellbeing of HIV Infected Person in Society
}

\author{
Lalitha. $\mathrm{V}^{1^{*}}$, Hemalatha. $\mathrm{S}^{2}$, Vanaja $\mathrm{P}^{3}$, Jayanthi. $\mathrm{A}^{4}$ \\ ${ }^{1}$ Associate Professor, Department of Pharmacology, Nandha College of Pharmacy, \\ Erode, Tamilnadu, Email: sasiikv@gmail.com \\ ${ }^{2}$ Associate Professor, Department of Pharmacy Practice, Nandha College of Pharmacy, \\ Erode, Tamilnadu, Email: hema.mpharm@gmail.com \\ ${ }^{3}$ Assistant Professor, Department of Pharmaceutical Chemistry, Nandha College of \\ Pharmacy, Erode, Tamilnadu, Email: vanaja@nandhapharmacy.org \\ ${ }^{4}$ Assistant Professor, Department Child Health Nursing, Nandha College of Nursing, \\ Erode, Tamilnadu, Email: jayanthijosesss@gmail.com \\ ${ }^{\star}$ Corresponding Author
}

\begin{abstract}
This paper aims to starts through an analysis of the historic situation of Human Immuno Virus and AIDS. Encompassed in this historic outline, is a description of Human Immuno Virus /AIDS and appropriate genetic procedures to offer a basis for the conversation of psychosocial, behavior, and demographic reasons related to Human Immuno Virus /AIDS well-being results and medicine observance. the theoretic background was taken to theorize these reasons and offer practical sustenance for the present study. Furthermore, the study deliberated the position of this education and how the study is proposed to sustenance the necessity for consolidative attention in Human Immuno Virus /AIDS therapy.
\end{abstract}

Keywords: HIV, well-being, AIDS.

\section{Introduction}

\section{Epidemiology and Historical Context}

Out Of all the worldwide wellbeing emergencies that have happened, some consume needed by way of destructive an effect in current periods as Human Immuno Virus /AIDS. Individually, it is too unevenly spread crosswise the world's people. Virtually 4 periods before, the primary sign of a bizarre immunodeficiency, unusual resourceful contaminations, and Kaposi's sarcoma be primary noted in youth gay males in the US. These comments gestured the begin of unity of the maximum physically, expressively, and administratively frightening widespread of the period. Whereas this is the instance, we consume remained able to study and know additional about the Human Immuno Virus infection in addition developed immunodeficiency syndrome in a small time than may be any illness in history. Plentiful of what has stayed exposed has level remained pragmatic to investigate on extra illnesses like cancer. Throughout the start of this wellbeing disaster, prominence was located on recognition of at-risk inhabitants but has lifted in new ages to attention on considerate performances which put persons at peril of conveying or constricting the virus.
The Human Immuno Virus is a virus which is spread through physical fluids and attacks the body's resistant system by abolishing CD4 cells, or T cells. This injury to the immune system declines the body's capability to fight off poisons and illness. If left unprocessed, Human Immuno Virus can last to lessen the sum of CD4 cells in the physique creation persons who have been disease more inclined to opportunistic poisons or cancers. Human Immuno Virus endures to be a main issue in worldwide community well-being with an appraised 36.7 million persons alive with the virus. While the major part of Human Immuno Virus cases have been identified in sub- Saharan Africa, civilizations universal are pretentious by the virus.

AIDS is defined usually as a set of situations that are symptomatic of plain immunosuppressor operative connected to a Human Immuno Virus contamination. A decrease in CD4+ T lymphocyte below $500 / \mathrm{mm} 3$ reflects this severe immune suppression. Dual dissimilar types of Human Immuno Virus, Human Immuno Virus - 1 and Human Immuno Virus -2, affect persons. Considerable indication exists supportive the theory that Human Immuno Virus - 1 in humans resulted from cross-species broadcast of a representative in chimpanzees, and Human Immuno Virus -2 from cross-species spread from dirty 
mangabeys. Three groups of Human Immuno Virus -1 have been predictable: groups $M, N$, and 0 . The main part of the world's poisons are with the Human Immuno Virus - 1 group $M$ viruses, of which some 10 changed subtypes exist. In the US and the Australia, Europe and Americas subtype B predominates. Subtype $C$ has quickly brushed through much of India and Southern Africa.

Usually, after persons debate Human Immuno Virus, it is understood that they are talking of Human Immuno Virus - 1 . Collections 0 viruses are effectually controlled to Central Africa.

Human Immuno Virus -2 is less communicable than Human Immuno Virus -1, possibly due to the inferior virus-related consignment related with it through abundant of its natural history. Human Immuno Virus -2 is mainly constrained to West Africa, but has been recognized in separate cases cross ways all areas. Nations with greater West African emigrant inhabitants such as France, Portugal, and former Portuguese colonies have also had cases of Human Immuno Virus -2. Little indication exists to advise that transmissibility diverges among the subtypes of Human Immuno Virus -1. However, the subtypes remain of attention to researchers due to the perception providing by their supply which assistances in the comprehension of the feast of the Human Immuno Virus epidemic.

\section{HIV, Psychosocial Stressors, and Wellbeing}

Psychiatric illness was noticed initial in the Human Immuno Virus widespread. As such, Human Immuno Virus has extended been related with mental suffering counting nervousness, unhappiness, then additional over-all bad cerebral well-being consequences as it is a illness which meaningfully influences all features of happiness. An education led in the US in the 90 s displayed that $48 \%$ of grownups getting upkeep for Human Immuno Virus presented cyphers of at smallest one psychiatric illness on broadcasts within the preceding year. This education comprised 2,864 who remained managed a broadcast valuation for many psychiatric illnesses counting main unhappiness, dysthymic depression, widespread nervousness illness, and fright illness. Investigators in the Netherlands deliberate the relations between managing panaches, goal turbulences, and mental suffering in Human Immuno Virus -positive persons. It was elective from this teaching that these ordinary commotions strength consequence from Human Immuno Virus and related indications as healthy as the medicinal routine or related side- belongings. An additional new education led in 2013 says persons alive with Human Immuno Virus /AIDS to inspect the influences of social shame and adopted shame on mental happiness. Investigators decided that shame related with Human Immuno Virus theatres a dominant part in the growth of unhappiness and nervousness, particularly in persons who show negative managing panaches. In 2014, a education led by means of a illustrative public example in country South Carolina measured apparent pressure, disposition outline, and symptom-related suffering to healthier comprehend the connotation among indication suffering and mental issues between Human Immuno Virus optimistic people. Members remained 18 years of age or big and remained not captivating medicines to indulgence unhappiness or nervousness at the period of the education. The consequences presented that the toughest associations remained among exhaustion and indication incidence and exhaustion and indication suffering. These answers are significant in their influence to the works meanwhile preceding investigate has exposed that exhaustion is unity of the greatest shared indications stated by people alive with Human Immuno Virus /AIDS. Numerous educations in the initial 2000s provision these answers classifying robust associations among exhaustion and manifold events of mental suffering and mental suffering, reduction in routine doings, and bodily operative due to fatigue. Moreover, mental suffering has remained noticed in advanced stages in people alive with Human Immuno Virus who report feeling fatigue. These joint consequences display that there is a long-known past of the association among psychiatric suffering and Human Immuno Virus /AIDS identifies with robust provision for the significances of lasting suffering foremost to bad health performances and reduced excellence of life.

Mental pressure, sadness, and then suffering are universal with long-lasting disease. Shared bases of mental suffering in persons with long-lasting disease are the vagueness concerning one's upcoming national of health, unpredictability of indications or bodily uneasiness, and the influence on the person's household and relations. Educations of persons identified with plain disease have branded numerous important melodies for preservative emotional stability including a search for sense, efforts to improvement controller over disease, and efforts to improve self-esteem.

The instant mental influence next an Human Immuno Virus diagnosis is commonly one of acute distress manifested as depressed perceived stress, mood, shock, anger,anxiety, tension and irresistible invasive thoughts. The occurrence of these indications has not yet been determined. While these indications are characteristically mild, they can be plain and even disabling to the grade that they may encounter the standards for a diagnosable psychiatric illness.

\section{Depression and HIV}

Unhappiness establishes the additional greatest often experiential disease universal. AIDS feeling a degree of unhappiness which is meaningfully advanced, reaching after 20-40\%. Moreover, selfdestruction ideation inclines to be current amongst 
two thirds of affected role who are unhappy and the degree of self-destruction amongst unhappy patients.

Numerous issues that place affected role with Human Immuno Virus / AIDS at advanced danger for unhappiness are persons by contact to long-lasting pressure, inadequate communal provision, then inert managing panaches. Additional issues which donate to advanced danger of emerging unhappiness are nondisclosure of Human Immuno Virus position, various wounded, progressive disease, intemperance, material use, feminine gender, and individual or domestic past of self-destruction attempts, disposition illnesses, and nervousness illnesses. The most problems of long-lasting medicinal disease include gloomy indications. Educations consume exposed that unhappiness has a harmful effect on affected role excellence of lifetime, devotion to action, and action consequences. Contempt convincing investigate, gloomy circumstances remain underrecognized, underdiagnosed, and undertreated in medicinal hospitals, particularly in action middles absorbed on Human Immuno Virus /AIDS. Unhappiness must be a main anxiety for Human Immuno Virus /AIDS investigators and action providers as it can influence enduring arrogances to action. Persons by unhappiness frequently maintenance fewer around their individual care, performance unwarily, and have continuous spirits of impossibility.

Educations consume exposed an augmented occurrence of Human Immuno Virus amongst persons who have cerebral well-being glitches and an raised occurrence of unhappiness and additional cerebral well-being circumstances crossways persons who are Human Immuno Virus seropositive. Investigators traveling the connotation amid illness development and unhappiness in together males and females originate that persons with Human Immuno Virus who showed gloomy indications remained closely 2 times additional at danger of humanity than persons who did not. While an profusion of investigate has recognized the joining amid bodily disease and unhappiness, it has been stimulating to found the causal trail between the two. Unhappiness container touch resistant purpose; though, it may also be the consequence of illness development or bad lifetime proceedings.

\section{Adherence and HIV}

Adherence to medicine can be clear as the degree to which a being's conduct competitions the well-being upkeep routine set by a medicinal expert. Highly, this action routine must be decided upon by the health care expert and the enduring. Devotion includes captivating medicine properly, at the correct period, with the good incidence, and at the precise amount. Medicine adherence is vital for refining well-being consequences with doctors accenting $80 \%-95 \%$ devotion for best route of well- being consequences. Though, doctors investigating and giving Human Immuno Virus affected role propose $95 \%-100 \%$ adherence to antiretroviral medicine to obstruct the repetition of Human Immuno Virus in the flow, reinforce resistant operative, inferior probability of broadcast, and reduction the probabilities of emerging medication confrontation. Though numerous Human Immuno Virus routines now comprise a mixture of medicines to efficiently luxury persons, dual main types of antiretroviral medicines used are peptidase inhibitors and non-nucleoside opposite transcriptase inhibitors.

\section{Stress and Coping}

Supportive to comprehension the effect of Human Immuno Virus / AIDS on a separate are dual copies to envisage replies to stressors: the biopsychosocial/psychic perfect and the Transactional Typical of Tension and Manage. The initial admits that all peoples have several features of lifetime which relate with each other though the following consider stressors, responses to stressors, and the result of these responses.

In the circumstance of a separate who has remained identified with Human Immuno Virus, an separate is characteristically confronted by a sequence of workroom examinations, actions with medicinal providers, and medicines for medicines. Though significant, the person's mental reply, provision scheme, and mystical response also need care. Medicinal valuation, interference, and action does of Human Immuno Virus are the standard in numerous hospitals and activities in industrialized states, though passable care to mental, communal, and mystical subjects often deserted. For mental operative, it is significant to letter the customer's pre- Human Immuno Virus mental position and how it has different owing to the analysis of Human Immuno Virus. Separate expressive reply, severe mental indications, past of cerebral disease or material usage, and sensual operative must also be key mechanisms of a mental valuation. Concerning communal subjects, a customer's social contextual must be healthier unspoken to offer setting for the separate knowledge of analysis, alive with Human Immuno Virus, and single's psychosocial response to alive with Human Immuno Virus. Socioeconomic position may also offer pertinent info as to an person's susceptibility to isms such as discrimination, heterosexism, classism, and sexism. Additional communal issues to reflect are teaching equal, with whom with customer exists, domestic reply to analysis if Human Immuno Virus position was revealed, domestic construction, and association status.

Additional newly, works has started to smear the outline of pressure and managing replicas to Human Immuno Virus investigate and has removed emphasis to the part of pressure and managing in both the 
bodily and cerebral well-being of Human Immuno Virus + affected role. One investigate study which examined the assessment of intelligence credited to a Human Immuno Virus analysis designated that a optimistic individual sense donated to version to disease. This discovery highlights the position of thought of mental happiness in the influence of Human Immuno Virus on the separate and ropes that additional investigate is wanted in this part to inspire the growth of scientific cerebral well-being interferences meant at plummeting bad belongings of Human Immuno Virus -related pressure .

In adding to cerebral well-being subjects, huge pressure knowledgeable by a separate has been related with deprived ART devotion which can lead to reductions in the CD4 total letting for the propagation of Human Immuno Virus and level to medication confrontation. Medication confrontation is of a main anxiety exactly, which has remained a country of emphasis meanwhile there has remained a growth in affected role showing confrontation to ART over the historical insufficient years. The answers stated in the present works on cerebral well-being and Human Immuno Virus provision the essential for additional investigate on the influence of communal issues and cerebral well-being provision on the bodily and cerebral well-being of Human Immuno Virus positive persons. Though there are numerous issues swaying the exists of persons pretentious by Human Immuno Virus, it is vital to improvement a healthier sympathetic of the collection of stressors affecting this populace to assistance specialists, and health care and administration organizations involve in the growth of healthier teaching, plans, and medical interferences.

\section{Social Support Status}

Social support has extended remained traveled as a important constituent in well-being consequences for persons with long-lasting disease. For persons with Human Immuno Virus /AIDS, revelation of one's position is a sole procedure complexly linked to communal provision and influenced by issues such as competition, civilization, insight of stigma, family, children, sex associates, and cerebral well-being. Chaudoir, Fisher, \& Simoni (2011) studied works on revelation and its association to communal provision, cooperating to found a perfect which addresses the gaps in investigate on this topic. Their Revelation Procedures Perfect goals to provide an outline to abstract the procedure of revelation for persons alive with Human Immuno Virus /AIDS. These investigators stress that before industrialized replicas have absorbed on the ID of issues foremost to revelation such as illness development, apparent penalties, and stages of association familiarity somewhat than the consequences of revelation. The makers of the fresher procedures perfect contend that revelation has insinuations for together separate well-being and community well-being by consuming optimistic effects on general well-being and well-being performances. For instance, persons alive with Human Immuno Virus / AIDS strength attain better social provision after revelation hopeful honesty around rank and an alteration in performances and insights affecting one's wellbeing.

\section{Family and social stigma}

An analysis of Human Immuno Virus can hugely influence one's communal and domestic life. Fear of revealing one's status is mutual and frequently consequences after apparent communal stigma. Apparent communal stigma due to Human Immuno Virus analysis has been related with augmented longlasting pressure from communal separation and a reduced excellence of life. A powerfully held value in Mexico, familiarismo, takes an intelligence of faithfulness to the family. While family is surely a basis of great provision, it can also be a basis of important tests when seeing issues connecting to Human Immuno Virus, sensual location, and substance use. Persons who fear revealing their seropositive position to domestic memberships may separate from their provision scheme in turn cumulative stages of mental suffering. For persons who knowledge tests through their domestic component, it determination be significant for clinicians to comprehend the influence on the separate by way of healthy as to help them find alternative bases of support.

\section{Conclusion}

Drug adherence is energetic for Human Immuno Virus /AIDS patient. However, examine has exposed that adherence endures to be a problem between persons alive with numerous chronic diseases. In the United States, it is assessed that more than of affected role with long-lasting situations are nonadherent to their set medicine routines with a yearly price of nonadherence. Though Human Immuno Virus medicine has better and develop additional nearby in numerous shares of the world, rigorous adherence to the medicine leftovers an vital share of action for better well-being consequences, and evasion of virologic disappointment and medication confrontation. Mental and communal issues consume remaiwell-documented in investigate as causal issues to bad well-being consequences and deprived adherence to Human Immuno Virus. numerous issues causal to nonadherence are lateral belongings of medicine, busy schedule and portable, unbalanced alive circumstances, disease or unhappiness, material use, fear of revealing Human Immuno Virus position, or absence of health cover or moneys to shelter the price of medicine. This information ropes the essential for early interference plans and initial broadcast for danger issues which could donate to medicine nonadherence. Due to the erraticism originate in the works concerning adherence, there 
are current insinuations for recurrent educations and challenging inside new collections of persons crossways values and the essential for consolidative care and teamwork among medicinal authorities and cerebral well-being specialists. By rationalization care to comprise healthier message and teamwork between cerebral well-being specialists and doctors, there is greater possible for better enduring consequences, all-inclusive care, and better interference plans.

\section{References}

1. Cook, T.D. \& Campbell, D.T. (1979). Quasiexperimentation: Design and analysis issues for field settings. Chicago: Rand McNally.

2. Cramer, J. A., Roy, A., Burrell, A., Fairchild, C. J., Fuldeore, M. J., Ollendorf, D. A., \& Wong, P. K. (2007). Medication compliance and persistence: Terminology and definitions. International Society for Pharmacoeconomics and Outcomes Research, 2(1), 44-47. doi: 1098-3015/08/44

3. d'Adesky, A. (2004). Moving mountains: The race to treat global AIDS. New York, NY: Verso. DeCock, K.M. (2008). The global epidemiology of HIV/AIDS. In P.A Volberding, M.A. Sande, J. Lange, \& W.C. Greene (Eds.), Global HIV/AIDS medicine (pp. 1-12). Philadelphia, PA: Saunders Elsevier.

4. Field, A. (2017). Discovering statistics using SPSS. Thousand Oaks, California: SAGE Publications.

5. Folkman, S. (1993). Psychosocial effects on HIV infection. In L. Goldberger \& S. Breznitz (Eds.), Handbook of stress: Theoretical and clinical aspects. (pp. 658-684). New York: The Free Press.

6. Huynh, A. K., Kinsler, J. J., Cunningham, W. E., \& Sayles, J. N. (2013). The role of mental health in mediating the relationship between social support and optimal ART adherence. AIDS Care, 25, 11791184.

7. Ickovics, J.R., Hamburger, M.E., Vlahov, D., Schoenbaum, E.E., Schuman, P., Boland, R.I., et al. (2001). Mortality, CD4 cell count decline, and depressive symptoms among HIVseropositive women: Longitudinal analysis from the HIV Epidemiology Research Study. JAMA, 282(11), 1466-1474.

8. Kiecolt-Glaser, J. K., Page, G. G., Marucha, P. T., MacCallum, R. C., \& Glaser, R. (1998). Psychological influences on surgical recovery. American Psychologist, 53, 1209-1218.

9. Kull, R.M. (2010). HIV history, illness, transmission, and treatment. In C.C. Poindexter (Ed.), Handbook of HIV and social work: Principles, practice, and populations (pp. 3-30). Hoboken, NJ: John Wiley \& Sons.

10. Lake, J. Integrative mental health care: A therapist's handbook. Norton: New York, NY. 